\title{
Unveiling the Concealed Vulnerabilities to Covid-19 of Low-Income People in Dhaka City: Consequences and Adjustments
}

\author{
Nazmoon Nahar Sumiya, Md. Humayun Kabir, Hafiza Khatun and Munira Nusrat
}

Department of Geography and Environment, University of Dhaka, Dhaka 1000, Bangladesh

Manuscript received: 25 August 2021; accepted for publication: 15 December 2021

\begin{abstract}
The present paper unveils vulnerabilities that remain among the low-income community in the megacity of Dhaka, while millions of people live in fragile housing conditions and depend on various informal economic activities. Based on extensive review of covid-19 related data collected from relevant institutions (e.g. IECDR), focus group discussions and case studies of the low income people living in three selected slums and some low income areas in Dhaka City, the present study explores that low income people have extremely been suffering from covid-19 pandemic induced lock-down. In addition to Covid-19 infections, the major concern of this group of people lies in the loss of income. As a result, most of them suffered tremendously from starvation and deprivation of some basic needs. Study findings also show that a significant part of this community left the capital city not being able to maintain them. In order to ensure the existence of this significant people with their support to the society, a special scheme of incentives should be provided while enhancing their resilience to the pandemic like covid-19.
\end{abstract}

Keywords: Covid-19, Low income people, Vulnerabilities, Consequences, Adjustments

\section{INTRODUCTION}

The outbreak of the coronavirus reported as covid-19 pandemic is one of the greatest challenges being faced globally since its emergence in December 2019 (UNDP, 2021). This novel pneumonic flu has infected more than 267 million people leaving nearly 5.27 million people dead worldwide till 10 December 2021 (WHO, 2021). The widespread transmission of covid-19 endangered millions of lives and disrupted the economy worldwide causing an immense burden on people's livelihood, healthcare and almost every other sector. In Bangladesh, the first cases of covid-19 were reported on 8 March 2020 (IEDCR, 2020a) and till 10 December 2021, about 1.578 million people have been infected, of those 28,017 people died (DGHS, 2021). This covid-19 pandemic has created an unprecedented economic and social crisis in Bangladesh (Kumar and Pinky, 2020). Bangladesh was hit by the pandemic at a crucial time when the country was making commendable progress on several economic and social indicators as the economy has graduated from the category of Least Developed

Corresponding author: Dr. Md. Humayun Kabir

Email: mhk.geoenv@du.ac.bd

DOI: https://doi.org/10.3329/dujees.v10i2.57511
Countries (LDC) on 24 November 2021 (UN, 2021) and aiming to achieve the status of an upper-middleincome country (UMIC) by 2041. Amid this progress in the economic sector, the unforeseen outbreak of the covid-19 has halted the pace of development at every level from local to global scale.

With the gradual increase of infected cases and death rate due to covid-19 worldwide after being reported first in China (Roques et al., 2020), the initial focus was to stem the transmission of the virus among the people as Non-Pharmaceutical Interventions (NPI) (Haug et al., 2020; Verschuur et al., 2021). Countries around the world, in line with the guidelines of WHO, imposed strict measures including lockdown, quarantine, mobility restrictions and practising social distancing (Atalan, 2020; Rouques et al., 2020; Haug et al., 2020; Verschuur et al., 2021; Onyeaka et al., 2021). Despite having variation in the implementation of lockdown both in domestic and international territories for different timespan across the world, the common issue was the resultant economic disruption worldwide specifically associated with the global supply chains (Verschuur et al., 2021 and Onyeaka et al., 2021). Overall, the initial approach of dealing with the covid-19 pandemic was to flatten the curve of infection and reducing the death tolls that resulted in the large scale implementation of lockdown despite 
the threat of a forthcoming global economic depression (Onyeaka et al., 2021).

The economy of Bangladesh largely depends on global supply chains, foreign remittances and of course on ready-made garments (RMGs) and thus the pandemic induced global recession ultimately affected the impressive growth trajectory of Bangladesh (UNICEF Bangladesh, 2020; Siddique and Faruk, 2020). Apart from this, almost $85 \%-90 \%$ of the total employment in Bangladesh is in informal sectors (Mujeri, 2019; Islam and Jahangir, 2020, Islam et al., 2020) covering multifarious jobs both in rural and urban areas that involves daily wage earnings and lack of any formal agreement makes these employment sectors fragile. A study conducted on the riverbank erosion victim slum dwellers of Dhaka by Dey (2021) identified that majority of the male members are involved with small business or street hawking followed by rickshaw/van puller and construction work. On the other hand, women are involved as garments workers followed by maidservant and construction workers. As a significant portion of the population in Bangladesh rely on daily earning (Chowdhury et al., 2020), the obvious aftermath of the covid-19 pandemic is a worsen situation causing economic recession (UNICEF Bangladesh, 2020).

Keeping pace with the global measures of controlling the pandemic, Bangladesh announced the implementation of nationwide subsequent lockdown in the initial stage in different phases starting from 26 March 2020 up to 30 May 2020 (Better work, 2021) to confine the spread of the virus. Starting initially as general holidays, the restrictions became stricter that ultimately resulted in a halted economic activity with some sectors (RMG, Finance etc.) be operating in limit. At the initial stage of the nationwide lockdown in March 2020, people tried to abide by the regulations (with few exceptions) but a couple of days later poverty pushed them to step outside amid this global crisis. The poor, low-income, and mediumincome people have been the worst victims of this pandemic as the lockdown directly impacted their lives and livelihoods (Paul et al., 2021).

According to Kabir et al. (2021), low-income people can be characterised as having lower income, less education, being employed mostly in informal sectors and living in slums or having no place of living. During the time of this pandemic low to middle-income people experiences severe challenges to sustain their livelihood because of joblessness, sudden closure of workplaces, restricted movement to earn daily wages etc. (Paul et al., 2021). Struggling from hand to mouth, most of these people faced severe difficulties and followed a range of adjustment strategies for survival by compromising their necessities. Therefore, this study aims to portray the struggle and challenges faced by the low-income people of Dhaka city during the covid-19 pandemic and associated lockdown.

\section{METHODOLOGY}

This study is based mainly on qualitative data combining perception study, case studies, group discussions and observations. To understand and explicate the background of covid-19 situation and transmission scenario in Bangladesh, several secondary literatures (journal articles, newspaper articles, govt. reports and relevant websites) have been reviewed. Thana wise number of confirmed cases for Dhaka City was available up to 12 September 2020 from March 2020 on the IEDCR website. This data has been used to map the distribution pattern of covid19 cases within Dhaka city. The dataset contained the number of confirmed cases for several locations of Dhaka city alongside the thanas. Therefore, additional information of those locations were incorporated with the associated thanas.

To identify the impact of covid-19 on low-income people of Dhaka city, 4 focused group discussions have been conducted in 3 slums in Kalabagan, Mohammadpur and Old Dhaka during the first weeks of August 2021. The participants of the first 3 FGDs were selected based on their availability, and representativeness for the targeted income group and gender. One FGD was particularly focused on the female participants to explore their vulnerabilities and domestic violence issues during the pandemic. For the first three FGDs, the number of people was 10-12 and for the fourth one, a group of 10 female participants joined. In addition, five case studies have also been conducted in these slums as well as other low income areas of Dhaka city to dig deeper to understand the challenges and consequences they have faced during the pandemic. The case studies were purposively selected from highly infected areas to comparatively low infected areas. The outcomes of these FGDs and case studies have played an important role in 
exploring the hurdles they faced as well as revealing their socio-economic vulnerabilities during this pandemic period.

\section{Distribution of Covid-19 cases in Dhaka City}

Bangladesh is one of the high-risk countries of the covid-19 pandemic and its consequent losses due to social and economic conditions. Having a population with a total of about 166.50 million (BBS, 2019) along with multifarious resource limitations, dealing with this unprecedented pandemic has been a great challenge in Bangladesh. Amidst battling with high population, poverty and resource scarcity, the poor management of covid-19 crisis unpleasantly exposed the fragility of our healthcare systems (Al-Zaman, 2020). In addition, lack of proper management policy and foreseeing the aftermath of nationwide lockdown without taking prior measures not only caused suffering to the people but also failed to achieve the estimated benefits of tackling the spread of this virus (Molla et al., 2021).
The density distribution of Bangladesh depicts a polarized scenario while the highest density is seen in the capital city, Dhaka followed by the other big cities (Khatun et al., 2021). Accommodating a high number of populations in the urban areas of Bangladesh especially in Dhaka city results in the development of low-quality living spaces like slums and squatters. Therefore, the number of cases of covid-19 infected persons has been seen significantly higher in Dhaka city (Figure 1).

The assigned authority to report and update the covid-19 related information is the IEDCR and based on their daily updates of the number of confirmed cases against testing, some of the areas with high infection rates within Dhaka city were identified where strict measures were imposed later. Till 12 September 2020, the thana wise distribution of covid cases shows that the highest numbers of confirmed cases $(6,408)$ have been identified in Mirpur followed by Ramna, Uttara, Mohammadpur, Dhanmondi and other thanas (Figure 2).

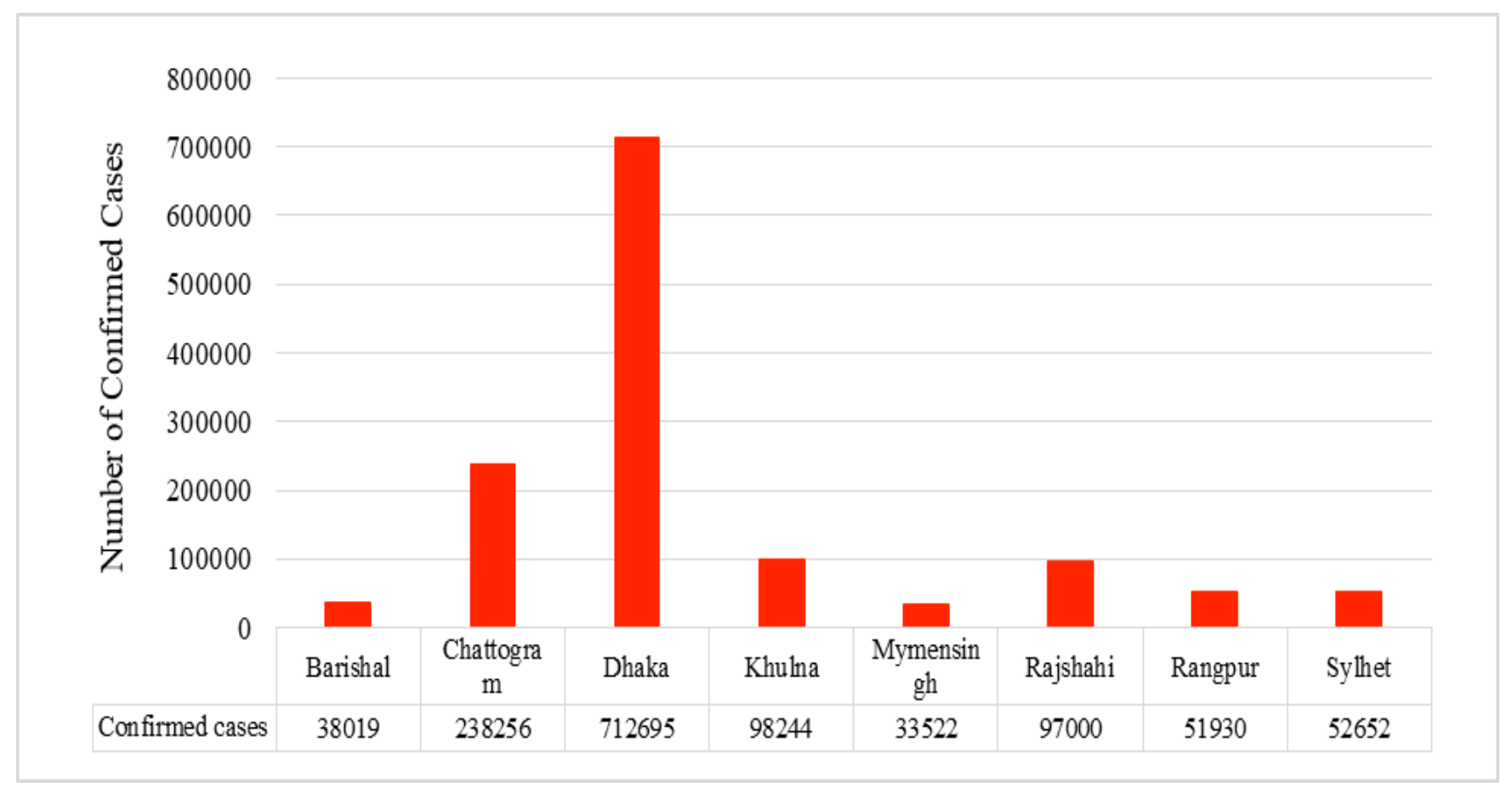

Figure 1: Number of Confirmed Cases of Covid-19 by Division from 8 March 2020 to 10 December 2021

(Data Source: DGHS, 2021) 


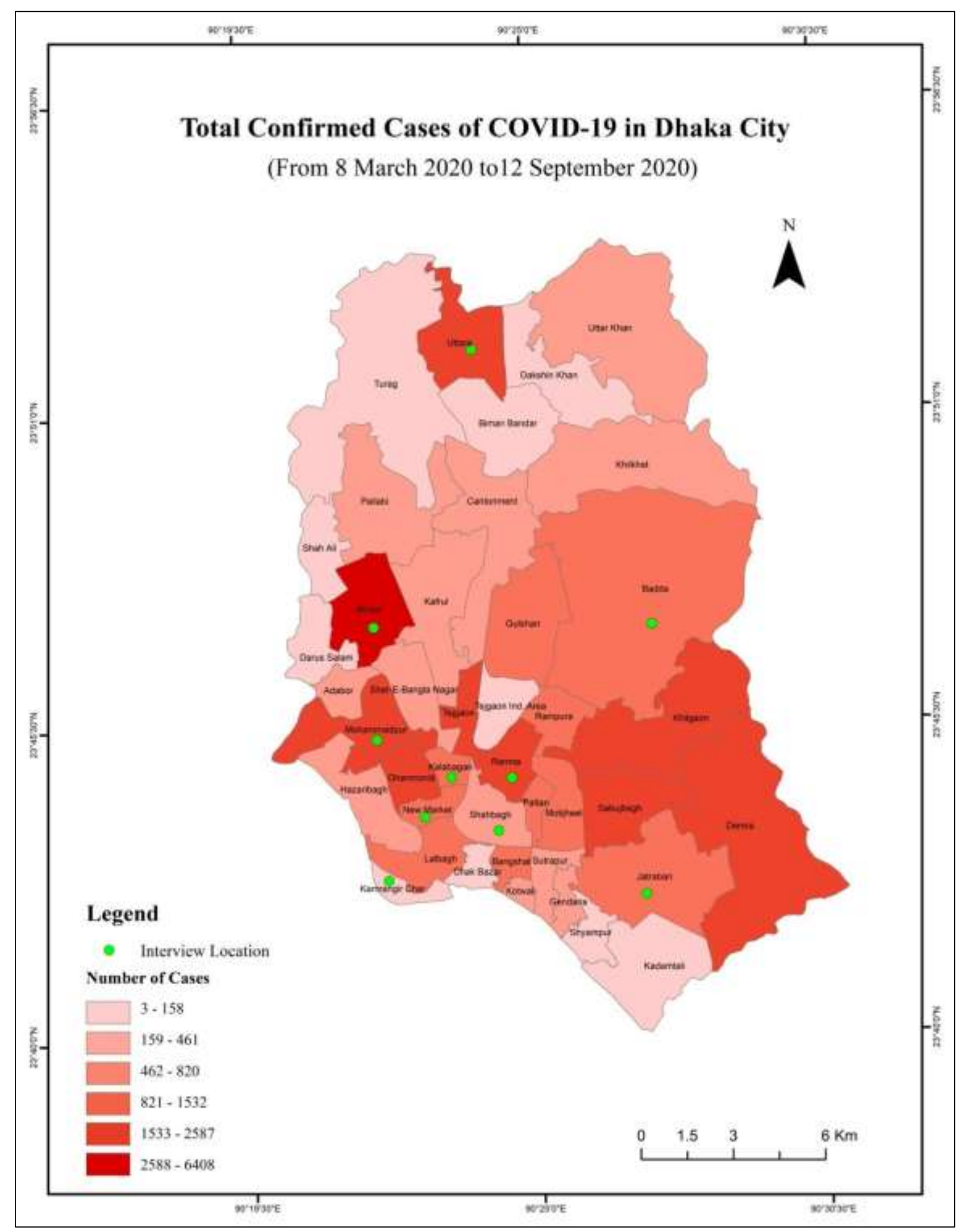

Figure 2: Number of Cases in Dhaka Infected by Covid 19 from 8 March to 12 September 2020

(Data Source: IEDCR, 2020 b)

Since the beginning of this pandemic to till date, the number of covid-19 tests being done daily is not satisfactory and thus experts fear a significant portion of the population carrying the virus might have been out of tracing (Al-Zaman, 2020) due to lack of testing facilities. On top of that, imposing a fee on covid-19 testing since June 2020, has substantially affected the number of tests per day (Hasan, 2020). Therefore, a 
lot of people remained outside of this testing process and so the actual infection rate of the low-income people remained unexplored.

\section{LoW-InCome People in DHAKa CiTy}

Dhaka is the capital and primate city of the country, centrally located with a good communication network and therefore people tend to migrate here as the city provides diversified opportunities (Khatun et al., 2021). With a very high population, a large share of the population (78.2\%) of Dhaka city is involved in informal sectors which provide a wide range of lowcost, labour-intensive, competitive goods and services (Rahman et al., 2020). The people mostly involved in these informal activities are low paid and do not have any formal agreement. In terms of salary, people earning between Tk. 40,000 to 80,000 per month are considered to belong in the middle class (Dhaka Tribune, 2021) and therefore, the people who have an average income below this range are the lowermiddle-income and low-income people. Being already in a vulnerable position due to living below the poverty line, these people are mostly involved in daily labour, hawking, street business, industrial works, transport works etc. (Sohel et al., 2021).

The capital city Dhaka contains nearly 3000 densely populated slums accommodating around six lac people (Islam et al., 2021). Prior studies on slums in Bangladesh identified that nearly $90 \%$ of slum dwellings are overcrowded and $48 \%$ of them possess a dwelling area of less than $9.3 \mathrm{~m}^{2}$ (Islam et al., 2019). Therefore, in this context, where the pattern of work and living arrangement of these people substantially require frequent physical contact in congested places like slums, these low-income people are at the risk of being affected by the covid-19 either physically or by its socio-economic causalities (Hasan et al., 2021 and Sohel et al., 2021). Moreover, the lack of access to pure drinking water and proper sanitation make defenceless against any type of viruses including covid-19 (Hasan et al., 2021) and therefore, considering the socio-economic settings, urban slums have been identified as potential hotspots for the spread of covid-19, (Sharif, 2020; Buckley, 2020; Corburn, 2020; Islam et al., 2021) and reservoirs for the spread of other viral respiratory infections (Adiga et al., 2018).

\section{Consequences of Covid-19 on Low-Income Group in Dhaka City}

This pandemic affected the low-income people in every possible way as they are one of the most vulnerable communities in society (Sohel et al., 2021). Increased cost of every utility with a reduced income made them suffer a lot during this pandemic. Measures taken to stem the spread of covid-19, especially the nationwide subsequent lockdown and travel restrictions made it difficult to sustain the livelihood of these people. The consequences of covid-19 on the life, livelihood and other sectors of these people are stated below.

\section{Impacts on Health}

Having limited access to health service, resources along with low educational background and inadequate earnings etc. trigger the vulnerability threats of low-income people. As their primary thinking is to sustain livelihood through earning, they hardly know about the guidelines to follow to control the transmission of covid-19 (Tampe, 2020; Islam, et al., 2021). Based on the understanding of the socioeconomic condition of the low-income people, it is easily predictable that they do not have much information regarding covid-19 and associated guidelines. Informal conversation with some of the representatives of this income group revealed that most of them do not have any clear concept about the symptoms of covid-19, the spread of the virus, selfisolation, quarantine, social distancing etc. Therefore, they are mostly unaware of the personal safety protocols needed to be followed during this pandemic. In addition, a vast majority of these people are reluctant to address their health issues and so most of them neither have any information regarding covid-19 testing and management issues nor have access to basic healthcare facilities. By force or by nature they ignore their health problems until it becomes a serious issue and that is why despite having symptoms similar to covid-19 they avoided the testing process. In addition to these, some of the interviewees expressed that they did not go for testing in the fear of being socially isolated and being evicted from their slum/living place if the result became positive.

Rahim (38 years), a rickshaw puller lives near Uttara, suffered from cold, body and headache with fever during the last weeks of October 2020. His wife who works as a Street side ruti seller also 
had the similar symptoms. Despite suffering, they continued their work and did not share this with anyone else. As they were living in a slum, they feared that they might be evicted from their place if other neighbours got to know about their symptoms. Fortunately, they got better after 10-12 days of having much weakness as a consequence and they were happy that they finally managed to hide this from others.

In addition to this, during the early days of this pandemic, different print and electronic media forecasted news of the VIPs and renowned personalities being infected. This somehow created a misconception that the virus will not affect the poor and this is another factor for them to be reluctant on this issue.

\section{Impact on Income and Employment}

The covid-19 induced lockdowns have triggered significant recessions and unprecedented levels of unemployment globally (McGann et al., 2020). In most cases, the urban populations have been hit harder, with low-quality jobholders, younger workers, and women more at risk of losing jobs across the world (Cueva et al., 2020; ILO, 2020). Similar to the global context, a majority of the working people of Bangladesh also faced wage reduction or was at risk of losing their job. A study by the World Bank found that nearly $76 \%$ of people in Dhaka city faced job loss due to covid-19 strict lockdown (Daily Star, 2021). Another report from April, 2020 revealed that nearly $6 \%$ of the working people lost their full income within 10 days of the covid-19 lockdown and nearly $50 \%$ of low-income and low-middle income people lost onethird of their income due to covid-19.

Another study conducted by two independent Bangladeshi research centres suggested that the average income of urban slums and rural slums in Bangladesh has declined by more than $80 \%$ since the start of the novel Coronavirus and also found a new poor group of about $21.7 \%$ due to this pandemic (PPRC-BRAC, 2021). Another study estimated that nearly $20.4 \%$ of the Bangladeshi population, or 33.0 million people, will newly fall into poverty due to this pandemic (Rahman and Matin, 2020). The emergence of this new poor group can be attributed to the reduced income and sudden loss of current jobs and a large number of low-income people were at risk of losing their jobs during the start of the pandemic (Ali and Bhuiyan, 2020). Temporary job loss due to lockdown in the country for the first two months (March-April) was estimated to be in between 12 and 17 million (Ahmed and Kamal, 2020).

Iftekhar, a 35-year-old gentleman, was a teacher at a kindergarten school in Mirpur. With the sudden announcement of nationwide lockdown starting from 26 March, 2020 his school was also declared to remain closed for the announced lockdown time without paying the salary of that month. As the lockdown was extended in several phases and the educational institution was closed for a prolonged time, the owner of that school sold the school to avoid losses. Sudden transformation of life compelled Iftekhar to send his family back to his in-law's house while he started struggling for jobs. Being tormented by the search for a job for the next six months, he finally started hawking vegetables to earn a living.

As it has been stated earlier that a substantial percentage of people of Bangladesh are involved in informal economic activities, it is predictable that these people have been in the most vulnerable condition due to covid-19 (Sakamoto et al., 2020). Around $80 \%$ of the informal migrant workers were not engaged in any work in the period of lockdown (Mahmood, 2020).

The pandemic decreased their income than their pre-covid income. Including public transport workers, day labourers, transport workers and housemaids were the worst affected among the major professions, having lost almost half of their income since the covid lockdown. Also, this lockdown situation not only made people jobless but also compelled them to shift jobs (Sohel et al., 2021).

Aklima Begum, a 36-year-old widow with a teenage daughter and a son, was living in Mohammadpur and worked as an attendant (aya) in a private orthopaedic clinic. Her income depended on the number of patients served by her per day. During the lockdown, the clinic received fewer patients that affected her earnings. She sent her children to her parent's home but after a month they were unable to bear the cost for her children. She eventually lost her job and having no other options, she started working with much reduced income as a cleaner to feed her children and herself. She also had to move to a shared house to adjust to her reduced income.

As it is getting more challenging to make a profit by doing street-based small businesses, people 
involved in this occupation faced more pressure and facing difficulties and were compelled to change their professions. Findings from group discussion in the slums reveal that the people living in slums involved in the street-based small and semi-small businesses were jobless for at least 4-6 months due to the lockdown and so they have no money to continue their business even after lockdown. As those people used all their savings to manage their daily life for the time being they were forced to shift their occupation as a result of this pandemic.

\section{Displacement and Moving Back to the Origins}

Evidently, people with lower socio-economic status were and are in a vulnerable position due to covid-19 (Raghunath and Tan, 2020). Initial declaration of lockdown was announced as general holidays that resulted in the mass movement of people to their village homes by intensifying the risk of spreading covid-19 (Daily Star, 2020; FAO, 2020). Though the initial movement was more of a festive vibe, with the extension of the government declared lockdown the scenario started to change. People were then forced to come back to Dhaka city for livelihood purposes.

In addition, due to the deployment of lawenforcement forces to ensure the effective implementation of lockdown resulted in temporary to permanent job loss. Therefore, people mostly of lowincome groups were partially migrating to the places from where they actually came from because of not being able to maintain the cost in the city. The findings from the FGDs revealed that most of the lowincome households where both parents are involved in informal activities sent their children to the villages to minimize their daily expenditure. Whereas, for the single-earner families, the wage-earning person decided to stay in Dhaka in search of work and the rest of the family were sent back to the villages. Some of these single earning family members moved to another location cheaper than the present one mostly due to the search for new employment opportunities. On the other hand, those who did not go back to their villages feared mostly the lack of employment opportunities in the village.

Mohammed Razzak (40 years), from Mymensingh, lived in KamrangirChar with his family of five members. He earned his living by a roadside rickshaw repairing shop with a toolbox and mostly stayed near the Dhaka University Campus area. His wife worked as a home maid and earned a major part of this family income. With this, they managed to maintain their family and children's education and their eldest son is a student of Mymensingh Agricultural University, elder daughter is a student of 12 grade in a college and the youngest daughter is a five-grade student in a local school. With the initiation of nationwide lockdown in March 2020, both Razzak and his wife lost their income, and they started living on their handful of savings expecting to see better days. With all savings been expended, they were forced to go back to their village home in August 2020. The hardship of them was beyond description as they could not manage any earning there. They faced a new problem in the village that is social pressure for marrying off their daughter as a mechanism of respite from poverty. All these situations pushed them back to Dhaka again for the search for work with an uncertainty of restarting their children's education.

\section{Social Complexities during Pandemic}

Maintaining social distancing and abiding by the regulations of the covid-19 measures have hardly been maintained by the low-income people that can be attributed to their ignorance, lack of education and awareness and most importantly prioritizing the wage earnings over personal safety. Besides, during the pandemic, the prime focus of people from every walk of life was on economic and health-related issues that overshadowed some other social issues related to this pandemic. Globally the increase of the issue of domestic violence, suicide and mental disorders have been noticed (Tandon, 2020) and similarly, Bangladesh faced these crises with lots of cases being unreported (Sifat, 2020). The female respondents of this study also expressed their experiences of facing domestic violence during the lockdown period.

In Bangladesh, a large number of women come to Dhaka in search of an additional income source for the family and work in informal jobs such as street vendors, housemaids, peddlers, etc. every year. The study of BRAC (2020) found that $65 \%$ of women entrepreneurs had no wages, while $58 \%$ of women working in the informal sectors had no employment because of the government's tight national lockdown. These women (90\% entrepreneurs and $84 \%$ informal sector workers) subsequently experienced social, economic, and mental difficulties, including domestic 
violence, decreased purchasing power and stress during the pandemic. This pandemic already caused indescribable misery and hardships in the life of slum dwellers. Already overcrowded homes with additional anxious family members confined indoors have also resulted in increased rates of gender-based violence under lockdowns (GiHA, 2020.

In order to keep the economic activities functional while managing the covid-19 crisis, some of the sectors like ready-made garments, food factories, financial institutions and relevant industries remained open without ensuring safety protocols. Therefore, the low-income people who already were unable to maintain the personal safety measures were compelled to continue working amid the risk of being infected.

Another social issue was exposed in the later period of the initial lockdown that families who were sent back to villages or live-in villages experienced early marriage incidents (Sakib, 2021) and many more are predicted to be the victims to this curse in the coming days due to this pandemic (UNICEF, 2021).

\section{Adjustment Strategies}

Lockdown measures that were the first response in many countries to deal with the pandemic were difficult to implement and unsuited for overcrowded settlements which made social distancing physically impossible, and these measures undermined survival opportunities of slum dwellers (Chirisa et al., 2020; Wasdani and Prasad, 2020). These low-income people were managing their expenditures only by working here and there temporarily. Some already changed their occupations to survive the economic crisis; some are also trying to do multiple types of jobs to cope with the situation. The major challenges that they faced are mainly shortage of income and food crisis. The cost of every utility is raising sky high, and they cannot afford even three times of food a day. A study showed that in two small cities in Bangladesh, the participants consumed less food quantity and compromised with food quality during the covid-19 lockdown crisis (Ruszczyk et al., 2020). This can lead to malnutrition, which can be a serious threat that will cause massive health hazards and will make them more vulnerable. They are trying to mitigate the situation by partially sending off the family members. The major coping strategy that has been observed during the interview is that they are cutting off their daily expenses by reducing food consumption and other things.

Gofur (36 years), one of the street food sellers said that he could not do any work in the first lockdown so he was jobless for about two and a half months and used all his savings which was very little in amount, to meet the expenses. But his savings were not enough and eventually he needed to take loans from others. At that time, he tried to find a job but could not find one. After the first phase of lockdown ended, he started selling foods again, but business is currently under a lot of loss as people do not want to eat street food because of fear of Coronavirus.

Taking loans from relatives or from money lenders was another key mechanism during the pandemic lockdown (Ruszczyk et al., 2020; Hossain et al., 2020 and Sohel, 2021). In some cases, people who did not have any option for borrowing money had been seen selling land, selling jewellery and goods to survive during lockdown (Sohel et al., 2021). The present study explores more or less similar ways of maintaining themselves during the new normal situation.

\section{CONCLUSION}

Globally, the covid-19 pandemic has severely hampered people's livelihood, especially in developing countries like Bangladesh. This unprecedented situation has created more difficulties for the slum dwellers living in Dhaka City. Lowincome people were the worst victims of this pandemic from health to socio-economic perspective. Reduced income, loss of employment and hurdles to find new income opportunities were the major financial challenges faced by these people. Compromising with food intake to cut down total family expenditure, sending back some of the family members to the villages, borrowing money, selling valuable possessions, and shifting occupation and living places were the vital adjustment strategies followed by these people. Though some of the people received help from a few government initiatives, local NGOs and charitable organizations, a large majority of the people were not reached. As a result of protracted deprivation from regular past income and assistance from any organizations, the marginalized group of the society have been fallen in tremendous vulnerability threats. With the ease down of the lockdown in recent months, the informal activities 
have been resumed but urgent incentives and government supports would be required to reinstate the lives and livelihood of these low-income people.

\section{REFERENCES}

Adiga, A., Chu, S., Eubank, S., Kuhlman, C.J., Lewis, B., and Marathe, A. (2018). Disparities in spread and control of influenza in slums of Delhi: findings from an agent-based modelling study. BMJ Open.

Ahmed, I., Kamal, S. M. (2020a June). Bangladesh at work in the era of COVID-19: Job creation and inclusive growth.

Bdnews24.com. https://opinion.bdnews24.com/2020/06/04/bangladeshat-work-job-creation-and-inclusive-growth-in-the-eraof-covid-19/Google Scholar.

Ali, M. and Bhuiyan, M. (2020, August). Around 1. $7 \mathrm{~m}$ youths may lose jobs in 2020 for pandemic. The Business Standard. https://tbsnews.net/bangladesh/around-17m-youthsmay-lose-jobs-2020-pandemic-121351

Al-Zaman, M.S. (2020). Healthcare crisis in Bangladesh during the Covid-19 pandemic. The American journal of tropical medicine and hygiene, 103(4):1357.

Atalan, A. (2020). Is the lockdown important to prevent the Covid-19 pandemic? Effects on psychology, environment and economy-perspective. Annals of medicine and surgery, 56:38-42. Available at: https://www.ncbi.nlm.nih.gov/pmc/articles/PMC72938 $50 \%$.

BBS (2019). Report on the Household Income and Expenditure Survey 2016, Bangladesh Bureau of Statistics, Statistics and Informatics Division, Ministry of Planning, Government of the People's Republic of Bangladesh.

Betterwork (2021). https://betterwork.org/portfolio/covidtimeline-in-bangladesh/ Accessed 10 September 2021.

BRAC (2020). Impact of Covid-19 on women entrepreneurs and informal sector workers. Available at:_https://www.brac.net/latest-news/item/1290-impactof-covid-19-on-women-entrepreneursandinformalsector-workers. Accessed 16 January 2021.

Buckley, R.M. (2020). Targeting the world's slums as fat tails in the distribution of COVID-19 cases. J Urban Health. 97, 358-364. doi:10.1007/s11524-020-00450w.

Chirisa, I., Mutambisi, T., Chivenge, M., Mabaso, E., Matamanda, A.R., and Ncube, R. (2020). The urban penalty of Covid-19 lockdowns across the globe: manifestations and lessons for Anglophone Sub-
Saharan Africa. GeoJournal. 1:1-14. doi: 10.1007/s10708-020-10281-6.

Chowdhury, D.R., Matin, D.I. and Franco, D. O. H. (2020). Social Crisis of Covid-19: Healthcare and the Balance of the Economy: A 20-Point Proposal. BRAC Institute of Governance and Development (BIGD).

Corburn, J., Vlahov, D., Mberu, B., Riley, L., Caiaffa, W.T., Rashid, S.F.; Ko, A., Patel, S., Jukur, S., Martínez-Herrera, E. and Jayasinghe, S. (2020). Slum health: arresting Covid-19 and improving wellbeing in urban informal settlements. J Urban Health. 97:34857. doi: 10.1007/s11524-020-00438-6.

Cueva, R., del Winkler, X. and Winkler, H. (2020). Blame Covid-19? But Blame Informality Too (or Maybe More). World Bank Blogs. Available online at: https://blogs.worldbank.org/jobs/blame-covid-19-

blame-informality-tooor-maybe-more. Accessed December 22, 2020.

Dey, A. (2021). Ambiguities of Masculinity after Riverbank Erosion Displacement: An Empirical Study on Perception and Experience of Displaced Male Slum Dwellers; Unpublished M.Phil Thesis, Department of Geography and Environment, University of Dhaka.

DGHS (2021). http://dashboard.dghs.gov.bd/ webportal/pages/covid19.php. Accessed on 11 December, 2021.

Dhaka Tribune (2021). Available at: https://www.dhakatribune.com/business/2021/06/02/ho w-will-the-budget-affect-the-middleclass\#: :text=In $\% 20$ terms $\% 20$ of $\% 20$ salary $\% 2 \mathrm{C} \% 20 \mathrm{pe}$ ople,fill $\% 20$ the $\% 20$ middle $\% 2$ Dclass $\% 20$ bracket.

FAO (2020). Impact of Covid-19 on informal workers. FAO Policy Brief. Available at https://www.fao.org/documents/card/en/c/ca8560en/

Gender in Humanitarian Action Working Group (GiHA WG) (2020). The Covid-19 Outbreak and Gender: Key Advocacy Points from Asia and the Pacific. New York, NY: UN Women. Available online at: https://asiapacific.unwomen.org/en/digitallibrary/publications/2020/03/the-covid-19-outbreakand-gender. Accessed March 5, 2021.

Hasan, K. (2020). Govt imposes fees on COVID-19 tests at state-run hospitals. Dhaka Tribune, June 29 Available at:https://www.dhakatribune.com/bangladesh/2020/06/ 29/health-ministry-fixes-covid-19-test-fees-at-tk200tk500. Accessed August 7, 2020.

Hasan, S.M., Das, S., Hanifi, S.M.A. Shafique, S., Rasheed, S. and Reidpath, D.D. (2021). A place-based analysis of COVID-19 risk factors in Bangladesh urban slums: 
a secondary analysis of World Bank microdata. BMC Public Health, 21, 502. Available at https://doi.org/10.1186/s12889-021-10230-z.

Haug, N., Geyrhofer, L., Londei, A., Dervic, E., DesvarsLarrive, A., Loreto, V., Pinior, B., Thurner, S. and Klimek, P. (2020). Ranking the effectiveness of worldwide Covid-19 government interventions. Nature human behaviour, 4(12):1303-1312. Available at https://www.nature.com/articles/s41562-020-01009$\underline{0}$.

Hossain, B., Sohel, M.S. and Ryakitimbo, C.M. (2020). Climate change induced extreme flood disaster in Bangladesh: implications on people's livelihoods in the Char Village and their coping mechanisms, Progress in Disaster Science, 6, doi:10.1016/j.pdisas.2020.100079.

IEDCR (2020 a). Covid-19 Key Statistics, Institute of Epidemiology, Disease Control and Research. Retrieved from https://old.iedcr.gov.bd/ website/images/files/nCoV/ 2020-03$08 \% 20 \mathrm{CoVID} \% 20$ Press $\% 20$ release.pdf Accessed on 1 November 2020.

IEDCR (2020 b). COVID-19 Dynamic Dash Board for Bangladesh, Institute of Epidemiology, Disease Control and Research. Retrieved from https://old.iedcr.gov.bd/website/images/files/nCoV/12_ September_2020.pdf

ILO (2020). COVID-19 crisis and the informal economy. ILO Brief, 2015(204): 1-8, Available at: https://www.ilo.org/global/topics/employmentpromotion/informaleconomy/publications/WCMS_743 623/lang-en/index.htm.

Islam, M., Adams, A., Mahmood, S., Iqbal, M., Chowdhury, R., and Razzaque, A. (2019). Slum Health in Bangladesh: Insights from Health and Demographic Surveillance. Dhaka: International Centre for Diarrhoeal Disease Research, Bangladesh (icddr,b).

Islam, R., and Jahangir, A. R. (2020). Corona fallout spells disaster for millions of poor Bangladeshis: Economists. United News of Bangladesh. Retrieved from https://unb.com.bd/category/Special/corona-falloutspells-disaster-for-millions-of-poor-bangladeshiseconomists/48533.

Islam, S., Emran, G.I., Rahman, E., Banik, R., Sikder, T., Smith, L. and Hossain, S. (2021). Knowledge, attitudes and practices associated with the Covid-19 among slum dwellers resided in Dhaka City: a Bangladeshi interview-based survey. Journal of Public Health, 43(1):13-25.
Islam, S., Islam, R., Mannan, F., Rahman, S., and Islam, T. (2020). Covid-19 pandemic: An analysis of the healthcare, social and economic challenges in Bangladesh. Progress in Disaster Science, 8.

Kabir, M.R., Islam, M.A. and Hossain, M.Z. (2021, July). Socioeconomic impact of Covid-19 on the lower middle and lower income people in Bangladesh. In AIP Conference Proceedings, 2347(1): 020268. AIP Publishing LLC.

Khatun, H.,Sumiya, N.N., and Ali, A.A.B. (2019). Achieving Sustainable Development Goals in Bangladesh: Does Population Density Matter? The Dhaka University Journal of Earth and Environmental Sciences, 8(2):1-15.

Kumar, B. And Pinky, S. D. (2020). Addressing economic and health challenges of Covid-19 in Bangladesh: Preparation and response. Journal of Public Affairs.

Mahmood, M. (2020).Covid-19: economic challenges facing Bangladesh, Financial Express, Dhaka, June 13.

McGann, M., Murphy, M.P. and Whelan, N. (2020). Workfare redux? Pandemic unemployment, labour activation and the lessons of post-crisis welfare reform in Ireland. International Journal of Sociology and Social Policy, 40(9-10): 963-978, doi: 10.1108/IJSSP07-2020-0343.

Molla, M.M.A., Disha, J.A., Yeasmin, M., Ghosh, A.K. and Nafisa, T. (2021). Decreasing transmission and initiation of countrywide vaccination: Key challenges for future management of COVID-19 pandemic in Bangladesh. The International Journal of Health Planning and Management.

Mujeri, M. K. (2019, March). Informality in the formal economy of Bangladesh. The Financial Express. https://www.thefinancialexpress.com.bd/views/informa lity-inthe-formal-economy-of-bangladesh

Onyeaka, H., Anumudu, C.K., Al-Sharify, Z.T., EgeleGodswill, E. and Mbaegbu, P. (2021). Covid-19 pandemic: A review of the global lockdown and its farreaching effects. Science Progress, 104(2):368504211019854, Available at: https://journals.sagepub.com/doi/full/10.1177/0036850 4211019854

Paul, A., Nath, T.K., Mahanta, J., Sultana, N.N., Kayes, A.I., Noon, S.J., Jabed, M.A., Podder, S. and Paul, S., (2021). Psychological and livelihood impacts of COVID-19 on Bangladeshi lower income people. Asia Pacific Journal of Public Health, 33(1):00-108.

PPRC-BRAC (2020). Covid-19 response-power and participation research Centre (PPRC). Available at: 
http://www.pprc-bd.org/what-we-do/covid-19 response/ . Accessed 27 January, 2021.

Raghunath, N. and Tan, T. (2020). The impact of social stratification on morbidity during the Covid-19 pandemic, International Journal of Sociology and Social Policy, 40(9-10): 793-806, doi: 10.1108/IJSSP07-2020-0261.

Rahman, H.Z. and Matin, I. (2020). Livelihoods, Coping, and Support during COVID-19 Crisis Dhaka, BRAC Institute of Governance and Development, Available at:https://bigd.bracu.ac.bd/wpcontent/uploads/2020/04/ Round-1_23_April_PPRC-BIGD-Final.pdf.

Rahman, M.S.U., Rahman, A., Sultana, S. and Nahrin, K. (2020). Informal Economic Activities in Residential Areas of Dhaka City: Empirical Evidence from Mirpur Area, Available at: https://www.researchgate.net/publication/345989892_I nformal_Economic_Activities_in_Residential_Areas_o f_Dhaka_City. Accessed on 30 November, 2021.

Roques, L., Klein, E.K., Papaïx, J., Sar, A. and Soubeyrand, S. (2020). Impact of lockdown on the epidemic dynamics of COVID-19 in France. Frontiers in medicine, 7:274. Available at https://www.frontiersin.org/articles/10.3389/fmed.2020 $.00274 /$ full.

Ruszczyk, H.A., Rahman, M.F., Bracken, L.J. and Sudha, S. (2020). "Contextualizing the COVID-19 pandemic's impact on food security in two small cities in Bangladesh", Environment and Urbanization, pp. 1-16. Available at: dro.dur.ac.uk/31796/1/31796.pdf, doi: $10.1177 / 0956247820965156$.

Sakamoto, M., Begum, S., Ahmed, T. (2020). Vulnerabilities to COVID-19 in Bangladesh and a reconsideration of sustainable development goals. Sustainability, 12(13).

Sakib, S.M. N. (2021). https://www.aa.com.tr/en/asiapacific/child-marriages-become-epidemic-duringpandemic-in-bangladesh/2396364.

Sharif, M. M. (2020). Opinion: Slums are the next front line in the fight against the coronavirus. Devex News. socioeconomic outcomes. International Institute for Labour Studies. Available at: https://www.ilo.org/wcmsp5/groups/public/dgreports/d comm/documents/publication/wcms_229105.pdf.

Siddiquee, D. M. S. H. and Faruk, A. (2020). COVID-19's Impact on Bangladesh Economy.

Sifat, R.I. (2020). Impact of the COVID-19 pandemic on domestic violence in Bangladesh. Asian journal of psychiatry, 53:02393.
Sohel, M.S., Hossain, B., Alam, M.K., Shi, G., Shabbir, R., Sifullah, M.K. and Mamy, M. M. B. (2021).COVID-19 induced impact on informal migrants in Bangladesh: a qualitative study. International Journal of Sociology and Social Policy, DOI 10.1108/IJSSP-02-2021-0046.

Tampe, T. (2020). Potential impacts of COVID-19 in urban slums: addressing challenges to protect the world's most vulnerable. Cities Health. 1-4. doi:10.1080/23748834.2020.1791443. [Epub ahead of print].

Tandon, R. (2020). COVID-19 and mental health: preserving humanity, maintaining sanity, and promoting health. Asian J. Psychiatry. 51 doi: 10.1016/j.ajp.2020.102256.

The Daily Star. (2020). Available at: https://www.thedailystar.net/frontpage/news/dhakaslums-where-covid-curiously-quiet-1936293.

UN (2021). https://www.un.org/development/ $\mathrm{desa} / \mathrm{dpad} / 2021 /$ graduation-of-bangladesh-lao-peoplesdemocratic-republic-and-nepal-from-the-ldccategory/\#: :text=On\%2024\%20November\%202021\% 2C\%20the,the $\% 20$ least $\% 20$ developed $\% 20$ country $\% 20$ category.

UNDP (2021). https://www.bd.undp.org/content/ bangladesh/en/home/coronavirus.html Accessed on November 1, 2021.

UNICEF Bangladesh (2020). TACKLING THE COVID-19 SOCIAL AND ECONOMIC CRISIS IN BANGLADESH: Providing universal, lifecycle social security transfers to protect lives and bolster economic recovery.

UNICEF (2021). 10 million additional girls at risk of child marriage due to COVID-19, available at https://www.unicef.org/bangladesh/en/pressreleases/10-million-additional-girls-risk-childmarriage-due-covid-19-unicef.

Verschuur, J., Koks, E.E. and Hall, J.W. (2021). Global economic impacts of COVID-19 lockdown measures stand out in high-frequency shipping data. PloS one, 16(4):0248818. Available at: https://journals.plos.org/plosone/article? $\mathrm{id}=10.1371 /$ journal.pone.0248818.

Wasdani, K. P., and Prasad, A. (2020). The impossibility of social distancing among the urban poor: the case of an indian slum in the times of COVID-19. Local Environ. 25:414-418. doi: 10.1080/13549839.2020.1754375.

WHO (2021). WHO Coronavirus Dashboard, World Health Organization, https://covid19.who.int/ table?tableChartType=heat Accessed On 10 December, 2021. 
